\title{
Politics of Cultural Commons: A Case Study of Sacred Groves in Central Kerala
}

Vinay Sankar ${ }^{\dagger}$

\section{Abstract}

Sacred groves or sacred natural sites (SNS) are defined areas of land and bodies of water with considerable socio-cultural and ecological value. This study attempts to analyse SNS using the framework of commons or common-pool resources and understand the implications regarding the access to and ecological sustainability of these sacred spaces. A set of ten groves from an inventory of sacred groves reported by the Institute of Foresters Kerala were chosen using purposive sampling to cover various types of custodianship and communities in the district of Thrissur. This district houses the most famous sacred grove in Kerala and is known for consecrating sacred groves and expunging spirits. A field survey employing an observation schedule and semi-structured interviews were undertaken focusing on the biophysical, socio-cultural and institutional aspects of the SNS. Understanding the relationship between grove ecosystems and stakeholder communities was the objective of the study. The management of SNS in the study sites does not show much evidence of collective action. There is a tendency of SNS to become 'club goods' over a period of time. Regardless of types of custodianship, SNS exhibit properties of common-pool resources from an ecological point of view. Even when customarily managed along caste lines, access was not physically restricted. Recent constructions of concrete boundaries around SNS, conversion of groves to temples and increasing intensity and frequency of rituals have changed the socio-cultural and ecological character of these spaces. The study shows that the perspective of the commons is inadequate to capture the underlying power dynamics of institutions of SNS. Understanding the transformation of SNS from being 'open' and inclusive to closed and elitist temple spaces need a different language of political ecology.

Keywords: Sacred Groves; Cultural Commons; Common Pool Resources; Political Ecology; Kerala, India

\footnotetext{
+ Ph.D. Scholar, Department of Humanities and Social Sciences, Birla Institute of Technology and Science (BITS), Pilani, Hyderabad Campus. Jawahar Nagar, Kapra Mandal, Medchal District - 500078, Telangana, India Email: vinay.sankar@gmail.com (C) 2020 Sankar. This is an Open Access article distributed under the terms of the Creative Commons Attribution License (http://creativecommons.org/licenses/by/2.0), which permits unrestricted use, distribution, and reproduction in any medium, provided the original work is properly cited.
} 


\section{Introduction}

Sacred groves or sacred natural sites (SNS), as they are mentioned in the literature, provide a wide range of ecosystem services such as maintaining soil and water balance, and pollination. They are repositories of rare flora and fauna and are sites of immense sociocultural significance (Rutte, 2011). Globally, they are recognised as an 'indigenous and community conserved area', or more generally, a 'protected area' (Berkes, 2009, p. 19). Gadgil and Vartak (1976), who first brought critical attention to SNS, described them as 'the most significant form of religious practice, economically speaking' (p. 152).

The groves operate in two closely inter-related, yet distinct planes-socio-cultural and biophysical (Samakov and Berkes, 2017). The 'presence' of a holy spirit or a presiding deity in the grove makes space a sacred one. Biophysically, the groves are 'mini forests', nestled amidst an agricultural landscape. 'Kavu theendiyal kulam vattum' (desecrate the sacred grove, and the pond will go dry) is an adage in Malayalam, portraying the ecological significance of SNS as mini watersheds.

SNS have exhibited features of common-pool resources. This feature is highlighted by studies such as Rutte (2011) and follows the way Ostrom (1990) and others have defined common pool resources. Ostrom (2005) defines commons or common pool resources as a natural or a manmade resource wherein it is difficult to exclude people from benefitting from them and has the feature of subtractability. The biophysical aspect of SNS conforms to this definition of commons. Hess (2008) considers that SNS takes the form of a 'cultural commons', under the broader category of 'new commons', since they are either under-researched or newly acquired the status of a commons.

Institutions, defined as 'distributional mechanisms that are power-laden' have governed the shared resource (Mahoney and Thelen, 2010). Institutional governance has often failed to protect the SNS from losing its cultural values and ecological richness. The governance failure has led to a significant reduction in the number of sacred groves in India, apart from the reduction in the size and quality of such groves, as confirmed by studies such as Gadgil and Vartak (1976), Ormsby and Bhagwat (2010), Burman (1996), Chandrashekara and Sankar (1998) and several others.

Ormsby and Bhagwat (2010) find that changes and overall ambiguity in the Forest laws led to the desecration of SNS in India. Burman (1996) notes that the push for plantation forestry by the local Forest Department resulted in the shrinkage of SNS in the Maharashtra region of Western Ghats. He also finds, contrary to many studies, that, there is no relationship between desecration of SNS and weakening of cultural and religious values. Vasan and Kumar (2006) contend that 'incentives from political economy and micro-politics' are responsible for their disappearance in Himachal Pradesh (p. 328).

Political ecology helps us to examine the relationship between economics, politics, and nature by critically situating issues in a historical and contextual setting (Robbins, 2012). It interrogates how political, social and economic factors affect nature/environment at different scales like local, regional and global through an understanding of environmental problems, concepts and actors (Bryant and Bailey, 1997).

In a similar way, Igoe and Brockington (2007) are categorical that neoliberalisation of nature involves reorganising the same through forms of commodification.Further, such commodification is undertaken through territorialisation, leading to marginalisation and exclusion of local users. Territorialisation implies that valuable areas like SNS are commoditised, transforming them into 'guarded enclaves'. According to Robbins (2012), control over access, aesthetics and landscape creation is political ecology. Smessaert, Missemer, and Levrel (2020) analyses the tendency towards monetary valuation, privatisation, and marketisation constituting the narrowly defined 'commodification chain'. 
Building on the conceptual framework of institutional analysis and design pioneered by Ostrom (1990), an analytical lens of institutional economics formulated by Rutte (2011) is employed in the present study (Table 1). Rutte (2011) conducted a meta-analysis of scores of SNS case study research from all over the world and found that they could be sorted into all four types of goods: private, club, common and public. A single tree or a handful of trees could purely be private property. Some of these groves could have been cleared- partially or fully- to construct temples, making it a club good, and here, 'spiritual' values trumps' natural' or conservation values. If the sacred grove is extensive in size, such as an entire mountain range, then it becomes impossible to exclude and becomes public property. It is when exclusion becomes difficult with a considerable portion of the complex still has natural surroundings, and the activities have to be regulated, it turns into a common pool resource or commons (Rutte, 2011). This classification is the perspective of the commons for SNS.

\begin{tabular}{|l|l|l|}
\hline Table 1: Institutional Economics Framework and SNS \\
\hline Rivalry & Exclusion easy & Exclusion difficult \\
\hline & $\begin{array}{l}\text { Private good } \\
\text { Small SNS having a spiritual entity connected } \\
\text { to the natural environment }\end{array}$ & $\begin{array}{l}\text { Common pool resource } \\
\text { SNS connected to natural } \\
\text { surroundings }\end{array}$ \\
\hline Non-rivalry & $\begin{array}{l}\text { Club good } \\
\text { SNS not connected to a natural environment }\end{array}$ & $\begin{array}{l}\text { Public good } \\
\text { SNS less connected to natural } \\
\text { surroundings }\end{array}$ \\
\hline Source: Rutte, 2011 & &
\end{tabular}

The present study attempts to delineate the nature of the relationship between SNS and various actors such as devotee and dependent communities, religious clergy, state and parastatal organisations like NGOs, representatives of temple committees in Kerala, India. Understanding the relationship is crucial in terms of implications for socio-cultural equity and ecological sustainability of sacred groves in Kerala. The literature is inconclusive about the conditions under which communities decide to maintain a sacred grove equitably and sustainably. The objective is to understand the socio-cultural and economic factors behind the desecration of SNS by unpacking the process of access to, utilisation of and barriers in sacred groves.

The study is divided into five sections. It begins with a brief description of the research setting and the rationale for choosing the same. Following this, it outlines the methodology used. It is followed by the sections presenting the results of the study, and discussion on relevant findings. The final section reflects on the concluding thoughts from the analysis.

\section{Research Context}

The present study is conducted in the district of Thrissur, Kerala, for the following reasons:

- Thrissur is considered as the cultural capital of Kerala, for its 'rich history, cultural heritage and archaeological wealth' (Directorate of Census Operations Kerala, 2011, p. 9). This district is famous for temples like Guruvayur and Kodungallur. The latter houses the Sri Kurumba Bhagavathi Kavu, and 'kavu' is sacred grove in Malayalam.

- 'Pambumekkat Mana', the 'most famous Serpent worship centre in Kerala' (Directorate of Census Operations Kerala, 2011, p. 186) is in Thrissur. It has enormous influence and clout among the communities associated with the sacred groves in Kerala. In many cases of desecration, they are often called for 'expunging the spirits', after which the site is cleared.

Thrissur district, covering an area of 3032 sq. km is juxtaposed between the Western Ghats in the east and the Arabian Sea on the west. It has 
three distinct natural features - the uplands, the plains and the seaboard (Directorate of Census Operations Kerala, 2011). As per the 2011 census, the density of population is 1031 per sq. $\mathrm{km}$. The literacy rate is close to $96 \%$. The Kole paddy fields constituting a significant wetland ecosystem for Thrissur and adjacent Malappuram district is a Ramsar site and is threatened due to the fast pace of urbanisation.

There are 970 sacred groves in this district, as per the report submitted by the Institute of Foresters Kerala (IFK) (2016). A summary of custodianship details is given in Table 2.
Recognising its immense conservation value as well as the reports that such sacred groves are fast disappearing, the state government had implemented a grant assistance program for the protection of such sites. The Social Forestry wing of the Forest Department was given the responsibility to identify sites and release the grant beginning from 2010. This responsibility has been entrusted to the local selfgovernments currently. Twenty-eight sites were identified all over Kerala under this program. Two of them are in Thrissur and were visited by the author, in addition to eight other sites. The next section describes the materials and methods.

\begin{tabular}{l|l|l|l|}
\hline \multicolumn{4}{|l|}{ Table 2: Overview of Custodianship of Sacred Groves in Thrissur District } \\
\hline S. No. & Custodian & No. of SNS & Extent (Cents) \\
\hline 1 & Sacred Grove under direct Government custody & 1 & $\mathbf{5 . 0 0}$ \\
\hline 2 & Sacred Groves managed by Devaswom Board & 5 & $\mathbf{2 1 5 . 5 0}$ \\
\hline 3 & $\begin{array}{l}\text { Sacred Groves managed by Public Trust/ Public } \\
\text { Committees }\end{array}$ & 14 & $\mathbf{1 8 4 . 0 0}$ \\
\hline 4 & $\begin{array}{l}\text { Sacred Groves managed by Individual } \\
\text { families/Group of families/Family Trust }\end{array}$ & 950 & $\mathbf{7 6 3 4 . 5 0}$ \\
\hline & Total & 970 & $\mathbf{8 0 3 9}$ \\
\hline
\end{tabular}

\section{Materials and Methods}

\section{Data Collection}

A qualitative field study was conducted in June 2018. Before that, from the IFK report (2016), a digital map of the universe of sacred grove sites in Thrissur was prepared. A purposive sampling method was employed to cover various types of custodianship structures across various communities managing these groves (Table 3 ). Chandrashekara and Sankar (1998) mention that, in Kerala, three types of management systems for groves exist. They are an individual family, group of families, and statutory agencies like Devaswom Boards, entrusted with the management of temples. Out of the ten sites visited, two were selected as they had received grant assistance from the state government in 2010. Those groves are managed by two marginalised communities- one belonging to a Scheduled Caste (SC) community, and the other a part of the Other Backward Classes (OBC). In
India, the caste system is a jati stratification of society, and jati denotes caste (Mukherjee, 1999, p. 1759). Government of India classified the caste hierarchy as follows: 'the high castes, other backward classes, the scheduled castes and the scheduled tribes' (Mukherjee, 1999, p. 1761). In the study district of Thrissur, the SC population is $10.39 \%$, and the ST is only $0.3 \%$ of the total population (Directorate of Census Operations Kerala, 2011, p. 16).

An open-ended snowballing approach was used to select the eight sites out of ten. An observation schedule was employed to understand the biophysical, social and institutional aspects for each of the sites. Semistructured interview schedules were used to interview actors such as representatives of NGOs, Forest Department, Gram Panchayats, and private individuals such as grove custodians/managers, representatives of local temple committees managing sacred groves, devotees and farmers. 
As shown in Table 3, three sites belonged to Namboothiri Brahmin family (part of the Devaswoms; the dominant Nair community- dominant clergy); and another one belongs to a managed three; one under the custody of a Thiyya (OBC) community.

\begin{tabular}{|c|c|c|c|c|}
\hline Site & $\begin{array}{l}\text { Area in } \\
\text { cents }\end{array}$ & $\begin{array}{l}\text { Characteristic } \\
\text { Features }\end{array}$ & $\begin{array}{l}\text { Custodianship } \\
\text { Type }\end{array}$ & Community \\
\hline Kapplianghat & 3 & $\begin{array}{l}\text { Compound wall } \\
\text { (CW) }\end{array}$ & $\begin{array}{l}\text { Local temple } \\
\text { committee }\end{array}$ & Thiyya, OBC \\
\hline Kappiyoor & 10 & Open/unfenced & $\begin{array}{l}\text { Local temple } \\
\text { committee }\end{array}$ & Nair, General \\
\hline Chukkath & 25 & $\begin{array}{l}\text { Pond, CW on two } \\
\text { sides }\end{array}$ & $\begin{array}{l}\text { Private family } \\
\text { trust }\end{array}$ & Ezhava, OBC \\
\hline Chedenghat & 10 & $\begin{array}{l}\text { Riverbank, well, } \\
\text { constructions } \\
\text { inside }\end{array}$ & $\begin{array}{l}\text { Private family } \\
\text { trust }\end{array}$ & Padanna, SC \\
\hline Kaveed & $\mathrm{Nil}$ & Temple & $\begin{array}{l}\text { Devaswom } \\
\text { Board }\end{array}$ & - \\
\hline Pambumekkat & 300 & Compound wall & $\begin{array}{l}\text { Private family } \\
\text { trust }\end{array}$ & $\begin{array}{l}\text { Namboothiri, } \\
\text { General }\end{array}$ \\
\hline Marath/Puthukulangara & 2.5 & $\begin{array}{l}\text { Barbed wire } \\
\text { fencing, concrete } \\
\text { platform }\end{array}$ & $\begin{array}{l}\text { Individual } \\
\text { private property }\end{array}$ & Nair \\
\hline Satram & 2 & - & $\begin{array}{l}\text { Devaswom } \\
\text { Board }\end{array}$ & - \\
\hline Mammiyoor & 1.5 & $\begin{array}{l}\text { Pond, concrete } \\
\text { platform }\end{array}$ & $\begin{array}{l}\text { Devaswom } \\
\text { Board }\end{array}$ & - \\
\hline Thekkekara & 3 & $\begin{array}{l}\text { Compound wall, } \\
\text { constructions }\end{array}$ & $\begin{array}{l}\text { Individual } \\
\text { private property }\end{array}$ & Nair \\
\hline
\end{tabular}

\section{Results}

The analysis of the sites having SNS revealed that except for the principles of congruence between costs and benefits, and collective choice, all are, mostly, in alignment with Ostrom's design principles (Table 4). Ostrom's design principles assemble 'lessons learnt' from successful and not so successful self-governance systems (Ostrom, 2010).

Physical boundaries are in the form of concrete compound walls in six cases, and barbed wire fencing in the remaining. Almost all of them were erected in the last 20 years. The social boundary is on the lines of religion (Hindu). Others would have to stand outside the physical boundary to pray and place offerings.

The principle of congruence between costs and benefits is seen as irrelevant in purely spiritual matters. The spiritual power is non-rivalrous, and any believer or seeker can have access to it at no or a little cost, as long as it is maintained as an 'unrestricted space.' This aspect of spiritual commons is different from the generic commons in terms of rivalry and exclusion. Samakov and Berkes (2017) confirm the same, in 
their study on sacred sites in Kyrgyzstan. At the same time, as a biophysical commons, SNS performs various biological and ecological functions at no cost to the dependent communities. For instance, the water that flows out of SNS to the agricultural fields abutting the grove is nutrient-rich.

Regarding the principle of collective choice, the power to set or alter rules and regulations is wielded by a few influential men such as priests, elders and social elites. Women are entrusted mainly with maintenance functions such as cleaning the periphery of the grove and lighting a daily lamp. They seldom have an institutional role.

A fear factor arising out of the presence of a serpent spirit or a similar deity in the SNS serves as a no-cost monitoring mechanism. The fear aspect is recognised by communities across castes and religions in all the sites. Restrictions such as no dirtying of the grove and its premises, no cutting or chopping of trees or branches, no removal of even fallen twigs are all strictly followed by the devotees and others alike. Several participants shared the stories of past transgressions and dire consequences faced by the transgressors.

Principles of graduated sanctions and local resolution of conflicts are seldom invoked. Inadvertent violations are pardoned off through ritualistic cleansing, and the violator has to bear the expenses. Recognition of rights is evident from the various grant assistance programs initiated by the government to the custodians of select SNS. The assistance is provided, primarily, for the maintenance of the ecological integrity of the site.

Ironically, ecologically speaking, five out of nine sites are in a highly disturbed condition. These five sites include the ones assisted by the grants. In most cases, participants mentioned that the SNS had a higher vegetative cover before and were more prominent in size. The norm of 'no removing and no improving', which traditionally governed SNS, has been violated. The impacts are visible in the reduction of the size of the grove, constructions inside the grove and compound walls around SNS. The concrete boundary seems to have become the 'new enclosure', replacing the 'original enclosure' of vegetative cover safeguarding the 'spirit' inside. The recent construction of concrete boundaries enabled the discriminatory prohibition of access on the lines of religion and gender. Ironically, such 'protective' walls have been funded by state schemes meant to protect the groves.

Following the framework by Rutte (2011), the SNS under the present study could be classified, ranging from a pure private good to open-access public property (Table 5). Pambumekkat, though spread over three acres, is entirely off-limits for public. Four groves transformed into club goods, as temples have come up in its precincts, with considerably reduced vegetative cover. Two sites governed by Devaswoms, are relatively open access.

The tendency for sacred groves to become 'club goods' is a recent phenomenon. It seems that it is not difficult to 'disconnect' the spirit from nature. The process of a shift in belief- from aniconic nature worship to icon worship is visible. A compound wall and a concrete platform are becoming the new 'enclosure', slowly replacing the vegetative cover, as predicted by Rutte (2011). This development has clear implications for the access to and ecological integrity of the grove. 


\begin{tabular}{|c|c|c|c|c|c|c|c|c|c|c|}
\hline 站 & 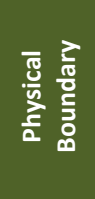 & 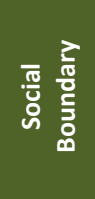 & 丞 & 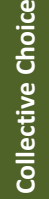 & 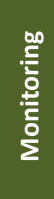 & 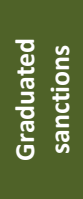 & 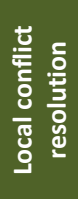 & 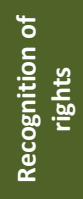 & 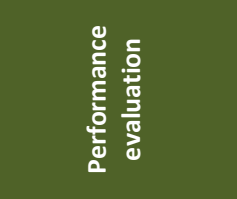 & 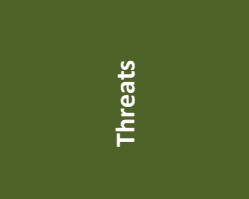 \\
\hline Kapplianghat & Yes & Yes & NA & No & Yes & Yes & Yes & Yes & $\begin{array}{l}\text { Powerful deity, } \\
\text { Old age, } \\
\text { Effective rules }\end{array}$ & $\begin{array}{l}\text { High disturbance } \\
\text { due to rituals }\end{array}$ \\
\hline Kappiyoor & Yes & Yes & NA & No & Yes & Yes & Yes & Yes & $\begin{array}{l}\text { Low disturbance } \\
\text { High \% of } \\
\text { vegetative cover }\end{array}$ & $\begin{array}{l}\text { Local committee of } \\
\text { elites }\end{array}$ \\
\hline Chukkath & Yes & Yes & NA & No & Yes & Yes & Yes & Yes & $\begin{array}{l}\text { Higher } \\
\text { biodiversity, } \\
\text { Regular rituals } \\
\end{array}$ & $\begin{array}{l}\text { High disturbance } \\
\text { due to daily rituals }\end{array}$ \\
\hline Chedenghat & Yes & Yes & NA & No & Yes & Yes & Yes & Yes & $\begin{array}{l}\text { Powerful deity, } \\
\text { Old age, } \\
\text { Higher vegetative } \\
\text { cover }\end{array}$ & $\begin{array}{l}\text { High disturbance } \\
\text { due to rituals }\end{array}$ \\
\hline $\begin{array}{l}\text { Kaveed } \\
\text { (Visited, but no } \\
\text { SNS exists) }\end{array}$ & - & - & - & - & - & - & - & - & - & - \\
\hline Pambumekkat & Yes & Yes & NA & No & Yes & Yes & Yes & Yes & $\begin{array}{l}\text { Old age, } \\
\text { High vegetative } \\
\text { cover }\end{array}$ & $\begin{array}{l}\text { Inaccessible } \\
\text { Opaque } \\
\text { management } \\
\end{array}$ \\
\hline $\begin{array}{l}\text { Marath/ } \\
\text { Puthukulangara }\end{array}$ & Yes & Yes & NA & No & Yes & Yes & Yes & Yes & Low disturbance & $\begin{array}{l}\text { Individual private } \\
\text { custodianship }\end{array}$ \\
\hline Satram & Yes & No & NA & No & Yes & Yes & Yes & Yes & Low disturbance & Open access \\
\hline Mammiyoor & Yes & Yes & NA & No & Yes & Yes & Yes & Yes & Highly disturbed & $\begin{array}{l}\text { Concrete enclosure, } \\
\text { temple visited by } \\
\text { many }\end{array}$ \\
\hline Thekkekara & Yes & Yes & NA & No & Yes & Yes & Yes & Yes & $\begin{array}{l}\text { Low vegetative } \\
\text { cover }\end{array}$ & $\begin{array}{l}\text { Concrete enclosure, } \\
\text { rituals }\end{array}$ \\
\hline
\end{tabular}

Source: Field Survey

\begin{tabular}{|l|l|l|}
\hline \multicolumn{2}{|l|}{ Table 5 Classification of SNS Based on Access and Barriers } \\
\hline Rivalry & $\begin{array}{l}\text { Exclusion Easy } \\
\text { Private good } \\
\text { Pambumekkat } \\
\text { Thekkekara/Puthukulangara } \\
\text { Marath }\end{array}$ & $\begin{array}{l}\text { Common pool resource } \\
\text { Non-Rivalry }\end{array}$ \\
$\begin{array}{l}\text { Club good } \\
\text { Kaplianghat } \\
\text { Kappiyoor } \\
\text { Chukkath } \\
\text { Chedenghat }\end{array}$ & $\begin{array}{l}\text { Public good } \\
\text { Satram } \\
\text { Mammiyoor }\end{array}$ \\
\hline \multicolumn{2}{|l|}{ Source: Field Survey } & \\
\hline
\end{tabular}




\section{Discussion}

Understanding the political ecology of SNS in Central Kerala is the primary objective behind this study. The literature is inconclusive about the conditions under which communities decide to maintain a sacred grove equitably and sustainably.

Applying a theme of political objects and actors, within political ecology, it is found that SNS in Central Kerala is being transformed by the actions of different agents/actors. Networking using power/influence (local temple committees of recent origin for example), SNS are facing 'unintended consequences and often pernicious results', such as a reduction in size (through temple construction), loss in biodiversity due to increasing disturbance, 'concretisation' of its natural premises, ultimately leading to its disappearance (Robbins, 2012, p. 232). The ' $N$ ' in SNS is relegated to the margins, and a 'sacred economy' takes over, over a period of time. In the name of protection and conservation, the SNS is silently and systematically dismantled by the very forces constituted for the protection purpose. Such actor-networks are dysfunctional, and that is the contradiction the present study intends to highlight.

Berkes (2009) mentioned that it would be an ideal situation 'if local common property institutions are consistent with conservation objectives like in the case of sacred groves' ( $p$. 20). The current study finds the opposite. In the present case, five out of nine sites visited had highly disturbed ecology with considerably reduced vegetative cover. Conservation values conflict with economic values. Concrete temple constructions have largely replaced naturebased belief systems.

In their study of SNS in Kerala, Chandrashekara and Sankar (1998) found that stakeholders like temple trustees, priests, and shop owners around the SNS have directly and materially benefitted by the offerings of devotees and tourists. The present study confirms that such benefits have emanated from the transformation of SNS as an ecosystem to a commoditised temple structure. Chandran and Hughes (1997) confirms that temple building leads to a diminution of the grove. More importantly, they find that rules meant to protect the grove are diluted as rituals become consistent with temples rather than flora and fauna.

Notermans, Nugteren, and Sunny (2016) conclude that a particular change in faith, rather than a loss of faith destroys SNS in Kerala. Every year elaborate rituals are performed as part of festivities such as kalamezhuthu pattu, guruthi and, karthika oottu. Rituals such as paalum noorum and sarpa bali are conducted regularly. Ayilya pooja is performed every month. Twice in a day, a lamp is lighted in the grove. These elaborate and often expensive rituals are consistent with temples, and not with ecologically sensitive entities like SNS. Arnold and Gold (2001) state that 'sacred landscapes may be constructed, manipulated, and otherwise re-imagined through cultural politics' (p. xv). The current study point towards the reimagining tendency in the case of SNS in Central Kerala.

If concrete constructions are incompatible with ecological sustainability, fencing off the grove using concrete compound walls have implications on equity in access. When enquired about the need to construct a compound wall around the grove, a priest had this to say:

it is required to keep non-Hindus, animals and women during their menstrual cycles away from the grove.

It disregards the fact that such enclosures are antithetical to the very idea of commons, and is hastening the process of managing them as yet another private or club good. Such territorialisation of cultural spaces is, unfortunately, the norm, rather than an exception, across sacred groves explored in this study. As long as the grove remained an 'open' ecological space, non-Hindu devotees and casual visitors could gain spiritual succour and experience aesthetic awe of the entity, even when standing on its periphery. Socio-cultural inequity is the result of such enclosures. The result is in concurrence with the prediction made by Rutte (2011) that spiritual value (presiding deity of the grove should not be disturbed, for 
instance) could come in conflict with economic values (transformation of groves into temples, in the present case). In the process, SNS becomes club goods, a result which is confirmed by the present study (Table 5).

Vasan and Kumar (2006) discern that the current political economy while encouraging the harvest of old groves also provides support for conservation and creation of new groves. They conclude that the conservation discourses are employed strategically to raise funds by the state as well as the NGOs. This 'environmentalist' turn was pointed out to the author in an interview with an NGO representative, working for the conservation of groves in Kochi. They have the vision to implement a notion of 'eco-spirituality'. As part of their work, his organisation provides economic and technical assistance to set up what is known as 'nakshatravanam' or star garden, as new age sacred groves. Based on the astrological birth star, a tree species is identified and planted in the premises of the house by the person born on that particular star. Such attempts to create new groves show that the notion of a sacred grove has great cultural significance even while losing its traditional ecological characteristics.

In a similar vein, Robbins (2012) finds that wilderness conservation changed complex cultural ecology spaces into commodified territories of consumption, striking at the root of ecosystem sustainability. Transformation of biodiverse sacred groves to concrete temples is at the expense of social and ecological sustainability. Building compound walls and platforms to install the deity denies access to a broader public (temples in Kerala often prohibits non-Hindus from entering temple premises), reduces and eventually destroys vegetative cover. Such walls hamper ecosystem functions and natural flows of elements.

Robbins is categorical that the division of nature and society is artificial and rooted in colonialism. In the name of conservation, control is exercised over resources as well as meaning and imagination of nature. Defining a place of cultural importance, and reshaping the space according to a dominant narrative of hegemonic
Hinduism is socially divisive and ecologically disastrous. An argument of 'inability' to keep menstrual 'discipline' was raised by a representative managing a sacred grove belonging to a Nair family, as a significant reason for the desecration of sacred groves. As Robbins points out, dominant paradigms of environmental conservation entailed territorialisation of conservation space and controlling proximate communities.

\section{Conclusion}

The present study shows that the stakeholder communities dependent on SNS have engineered an institutional change adversely impacting socio-cultural equity and ecological sustainability. The discussion above also point towards that analysing SNS through testing of Ostrom's design principles seems to be inadequate. It often fails to capture the 'community failure', if any. Several scholars attempted to employ the design principles to study SNS (Rutte, 2011; Samakov and Berkes 2016). However, as Hayek cautioned, 'common ends may not be ultimate ends to the individuals involved' (Hayek, 1944, p. 63); common pool resources often end up as private goods and club goods. Such transformation has social equity and conservation implications. The need for a political ecological framework emerges, asking 'central questions, such as: What causes forest loss? Who benefits from conservation efforts and who loses? (Robbins, 2012, p. 20)

Nonetheless, this study argues that the commons approach is necessary. This is because irrespective of the legal custodianship of sacred groves, the stake of a wider public as believers or seekers of spiritual succour makes it a common pool resource from a cultural perspective, apart from the standpoint of ecology. This collective aspect has been the inclusive feature of the sacred groves, even if the property rights are exclusive. This communal aspect assumes critical importance given the fact that the set of believers or seekers are not restricted to a particular caste, or even religion, in this part of the country. Nevertheless, as the current study shows, a commons framework is ineffective in capturing the underlying power dynamics. 
In conclusion, the study finds that SNS are transforming from being an inclusive, democratic and 'unrestricted' ecological commons, to an exclusive, elitist, 'closed' and increasingly concretised temple spaces controlled by private individuals through a complex process of political mobilisation. A 'politics of empty space', in the form of enclosures, privatisation and commodification, is steadily unfolding.

\section{References}

Arnold, P. P., \& Gold, A. G. (2001). Sacred landscapes and cultural politics: planting a tree. Ashgate.

Berkes, F. (2009). Community conserved areas: policy issues in historic and contemporary context. Conservation Letters, 2(1), 20-25.

Bryant, R. L., \& Bailey, S. (1997). Third world political ecology. Psychology Press.

Burman, J. R. (1996). A comparison of sacred groves among the Mahadeo Kolis and Kunbis of Maharashtra. Indian Anthropologist, 26(1), 3745.

Chandran, M. S., \& Hughes, J. D. (1997). The sacred groves of south India: ecology, traditional communities and religious change. Social compass, 44(3), 413-427.

Chandrakanth, M. G., Bhat, M. G., \& Accavva, M. S. (2004). Socio-economic changes and sacred groves in South India: Protecting a community-based resource management institution. Natural Resources Forum, 28(2), 102-111. https://doi.org/10.1111/j.14778947.2004.00077.x

Chandrakanth, M. G., \& Romm, J. (1991). Sacred forests, secular forest policies and people's actions. Natural Resources Journal, 31(4), 741756.

Chandrashekara, U. M., \& Sankar, S. (1998). Ecology and management of sacred groves in Kerala, India. Forest Ecology and Management, 165-177.

Directorate of Census Operations Kerala. (2011). District Census Handbook Thrissur. New Delhi: Government of India.
Gadgil, M., \& Vartak, V. D. (1976). The sacred groves of Western Ghats in India. Economic Botany, 30(2), 152-160.

http://www.jstor.org/stable/4253716

Hayek, F. (1944). Road to Serfdom. New York: Routledge.

Hess, C. (2008). Mapping the New Commons. International Association for the Study of Commons (pp. 1-75). Cheltenham: SSRN.

Igoe, J., \& Brockington, D. (2007). Neoliberal Conservation: A Brief Introduction. Conservation and Society, 432-449.

Institute of Foresters Kerala. (2016). Status Report on Sacred Groves in Thrissur, Kerala. Thrissur: Forest Department, Kerala.

Mahoney, J., \& Thelen, K. (2010). Explaining Institutional Change-Ambiguity, Agency and Power. Cambridge University Press.

Mukherjee, R. (1999). Caste in Itself, Caste and Class, or Caste in Class. Economic and Political Weekly, 34(27), 1759-1761. Retrieved August 30, 2020, from http://www.jstor.org/stable/4408152

Notermans, C., Nugteren, A., \& Sunny, S. (2016). The changing landscape of sacred groves in Kerala (India): A critical view on the role of religion in nature conservation. Religions, 7(4). https://doi.org/10.3390/REL7040038

Ormsby, A. A., \& Bhagwat, S. A. (2010). Sacred forests of India: A strong tradition of community-based natural resource management. Environmental Conservation, 37(3), 320-326. https://doi.org/10.1017/S0376892910000561

Ormsby, A. A. (2011). The impacts of global and national policy on the management and conservation of sacred groves of India. Human Ecology, 39(6), 783-793.

Ormsby, A. (2013). Analysis of local attitudes toward the sacred groves of Meghalaya and Karnataka, India. Conservation and Society, 11(2), 187-197. https://doi.org/10.4103/09724923.115722

Ostrom, E. (1990). Governing the Commons. Indiana: Cambridge University Press. 
Ostrom, E. (2005). Understanding Institutional Diversity. New Jersey: Princeton University Press.

Ostrom, E. (2010). Beyond Markets and States: Polycentric Governance of Complex Economic Systems. The American Economic Review, 641672.

Robbins, P. (2012). Political Ecology-A Critical Introduction. Sussex: John Wiley \& Sons.

Rutte, C. (2011). The sacred commons: Conflicts and solutions of resource management in sacred natural sites. Biological Conservation, 144(10), 2387-2394.

https://doi.org/10.1016/j.biocon.2011.06.017

Samakov, A., \& Berkes, F. (2017). Spiritual commons: Sacred sites as core of communityconserved areas in Kyrgyzstan. International Journal of the Commons, 11(1), 422-444. https://doi.org/10.18352/ijc.713

Smessaert, J., Missemer, A., \& Levrel, H. (2020). The commodification of nature, a review in social sciences. Ecological Economics, 1-10.
Vasan, S., \& Kumar, S. (2006). Situating Conserving Communities in their Place : Political Economy of Kullu Devban. Conservation and Society, 4(2), 325-346.

\section{Conflict of Interest}

The author has no conflict of interest to declare.

\section{Acknowledgements}

I sincerely appreciate the time and inputs provided by the participants of this study. I thank my doctoral advisor, Dr. Lavanya Suresh, for her constant encouragement. I also express my gratitude to the Department of Humanities and Social Sciences at the Birla Institute of Technology and Science (BITS), Pilani, Hyderabad Campus. I greatly appreciate the comments and suggestions received during the Sixth Annual Conference of Network of Rural and Agrarian Studies (NRAS) held in 2018 at the Central University of Gujarat, India. I am grateful to the two anonymous reviewers of the journal for their valuable comments. 